\title{
ENDOTRACHEAL INTUBATION OF INFANTS AND CHILDREN ${ }^{1}$
}

Harold T. Dąyenpoft, M B., F.F.A.R.C.S., and Jose K. Rosales, M.D. ${ }^{2}$

IT HAS BEEN stated that writers do not agree as to whether endotracheal intubation is easier or more difficult in children and infants than it is in adults (1). It may be instructive to describe our experience of the difficulties which occur during the insertion of endotracheal tubes in a children's hospital, where this procedure is performed very frequently.

Broadly, the main problems are anatomical or anaesthetic. Such basic difficulties as those which arise from lack of experience or lack of proper apparatus should not concern trained anaesthetists in reputable hospitals.

\section{Anatomical Problems}

Paediatric anaesthetssts have considered the small size of the larynx and trachea in children and infants to be a most important feature in their work. Attention has been drawn also to the more cephalad and more anterior position of the larynx, together with the "infantile" shape and lie of the epiglottis and the relative constriction withon the cricoid ring in young patients (2).

There is also a "crowding" of many structures in the region of the small oropharynx and,hypopharynx. This is partly due to the obtuse angle of the mandible $\left(175^{\circ}\right.$ at birth), which becomes more caudad relative to the fixed condyle and nearer to a right' angle in the adult $\left(135^{\circ}\right)$, ' and partly to the narrowness of the ramus which expands with growth. The infant tongue is also relatively larger.

Serial occlusion studies of the jaws show that the mandibular gum pad at birth is posterior to that of the maxilla and does not establish its correct relation until after one year of age (3). Prominence of the maxilla is usual until the fifth postnatal month and this may persist, or mandibular retrusion may exist. Either leads to poor support of the tongue base by the muscles attached to the mandible and obstruction to direct-vision endoscopy by the upper jaw. Immaturity of the alveolar ridges and teeth means that distortion and luxation can easily occur, as well as grosser traumatic damage. The cranium dominates the small body in younger patients. There is frequent $y$ excess of the adenoidal tissue or other impairment of the nasal airway.

There are also many specific pathological conditions which may deform the anatomy of the air passages. These may be of congenital, neoplastic, or infective origin.

\section{Consideration of Anatomical Problems}

As the larynx is more; anterior and cephalad, it is to be expected that the angle which exists between the laryngeal opening and the pharynx would be even more

1Presented at the Annual Meeting, Canadian Anaesthetists' Society, June 23-25, 1958

2From the Department of Anaesthesia of The Montreal Children's Hospital and McGill University, Montreal, Canada. 
acute than it is in adults (4) Thus, despite the relatively large head in the lower age groups, which gives some degree of flexion of the cervical region, when lyng on a flat surface, it is preferable always to increase this flexion by use of a pillow or "doughnut" type of headrest A laryngoscope with a total (5) or partal (6) curve of the blade will tend to further increase the antenor displacement of the glottus

In infants and chuldren we use a stranght laryngoscope blade in the manner recommended for the MacIntosh blade that is, we place the tp of the blade in the valleculae This is preferable for the reasons orginally stated (5), plus the fact that in children it is often difficult to lift the epiglotts (7) and because abrasion and contamination of the arytenoids and aryepiglottc folds by the laryngoscope may occur in the attempt If the broud tip of a straght laryngoscope is placed in the valleculae and slight pressure exerted anterior to the larynx in a posterior direction (Figs 1 and 2) a full view of the glottic opening is obtamed Owing to their softness in early life, neck structures are easily dislodged for this manouture by gentle digital pressure With thus method a nearly straight, soft plastic tube can be inserted without difficulty and any obstruction to its passage, due to the anterior commissure or angulation of trachea is unlikely (2) Owing to the fragility of the structures involved, we belreve that for general use very pliable endotracheal tubes have advantages (8)

Untl the teeth erupt, the gums are a serles of segments of active vascular ussue which nournsh the toothbuds In the very young the teeth-bearing margm of the maxilla is not resistant and can be easily indented by any excess pressure (Fig 3) Distortion from excessive pressure may lead to permanent displacement of facial structures and simple immediate remoulding is recommended in such mstances (9) The deciduous teeth in either jaw may be easily dislodged If a

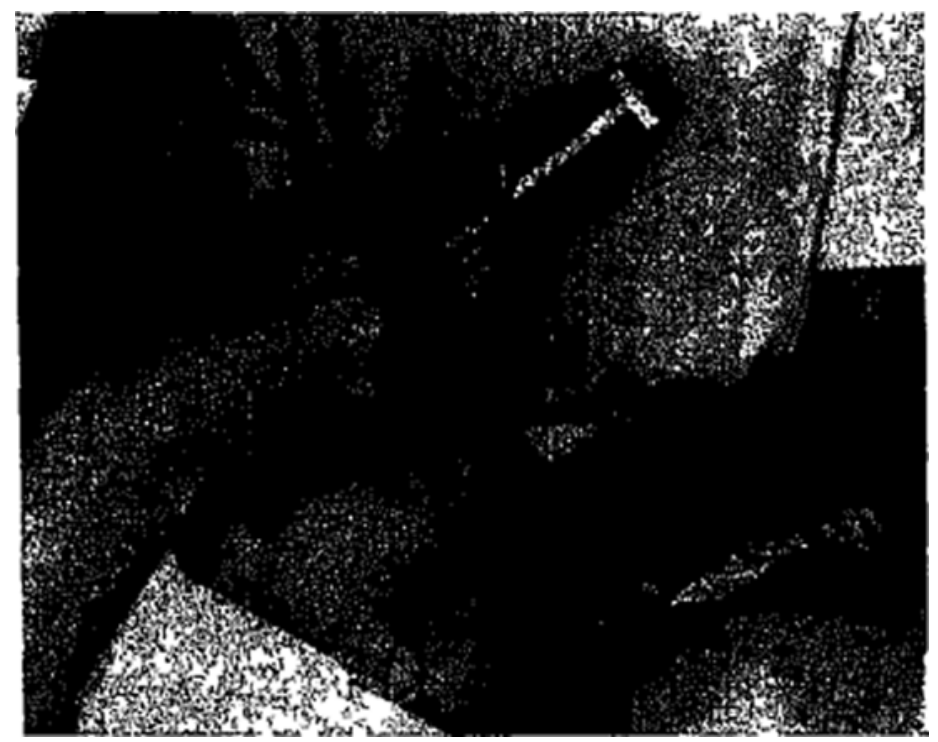

Ficure 1 A picture of intubation of the trachea being per formed with the tp of a straght laryngoscope blade in the valleculae and external backward pressure being applied to the larynx region 


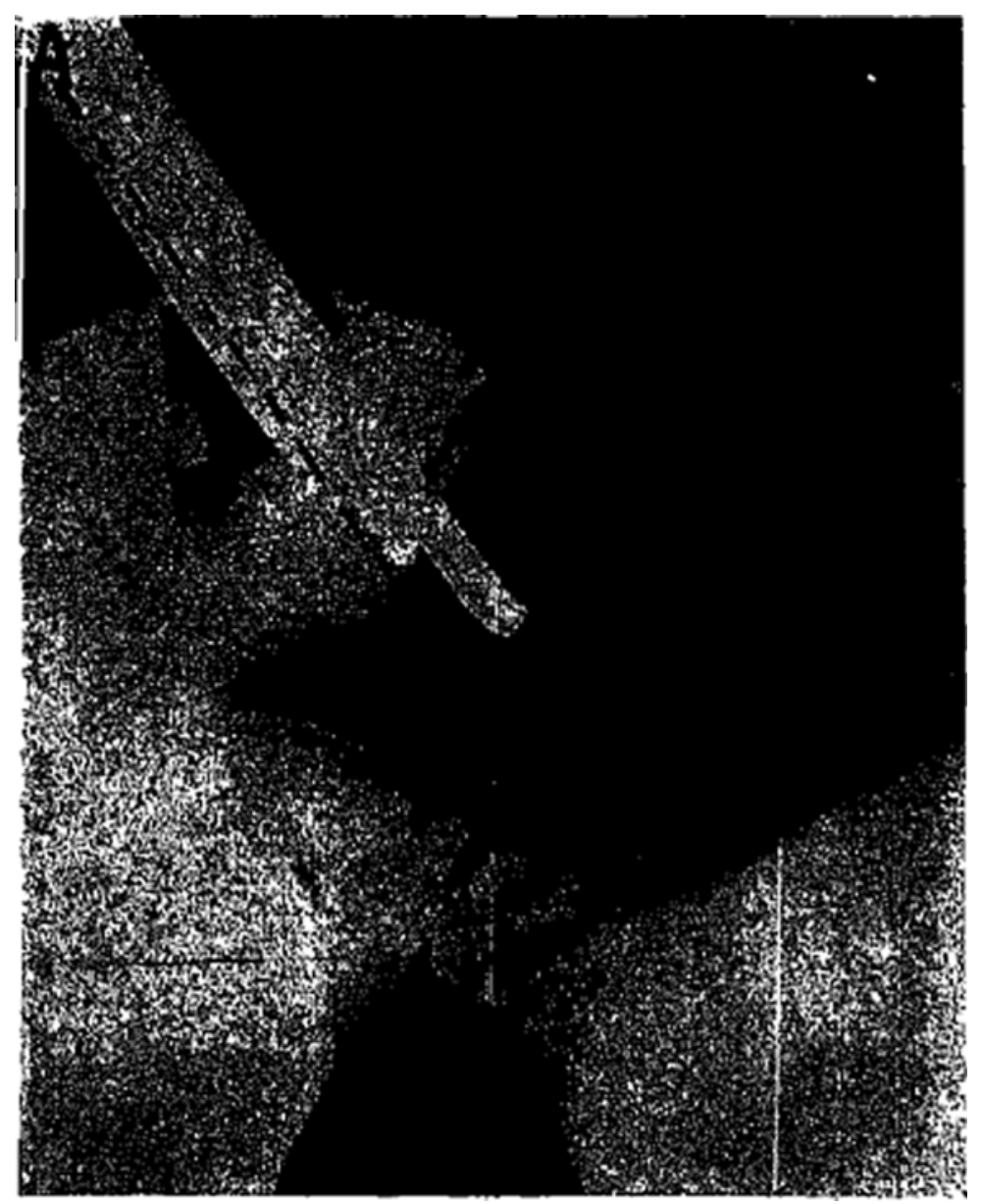

Ficurc 2 A roentgenogram of $\mid$ Figure 1 with the direct'line of visıon into the trachen indicated (A) and backward pressure bengs applied externally by the finger marked (B)

Ficune 3 Marked indentation of the right upper alveolar margin caused by cirect laryngoscopy during multiple attempts at Tesuscitation 
tooth is mislaid durmg intubation or durng anaesthesia and cannot be found, it is our usual practice to take a chest X-ray and if necessary do a bronchoscopic examinaton before the patent awakes

It is mportant to have a small laryngoscope blade with blunt edges for work with infants and to realize always that excessive pressure must never be used or some damage is nevitable Gentle technique may be encouraged by the use of a munature laryngoscope (10) or by a more obtuse angulaton between the laryngoscope handle and blade (11)

Nasal intubation is only practused when specifically indicated, for example, in certain plastic and dental procedures and ankylosis of the jaw It is curnous that the adenond tissue rarely complicates the insertion if soft tubes are employed, but rupture and penetration of the mucosa of the upper arrway may occur even w1th the greatest care (12)

Narrowing of the tracheal lumen withın the cricold ring has long been recognized This we have noted is sometmes associated with tracheo-oesophageal fistula, and a good range of sizes of tubes must always be avallable Laryngeal and subglottic webs and strictures are uncommon and only five cases of tracheal atresia have been described (13). Thyroglossal cysts, cystic hygromata, and mucous cysts of the' epiglottic region are also rare, they may encroach on the aurway but they do not usually lead to senous dufficulty when the patient is beng mtubated Haemangiomata, neuroblastomata, and anomalous vessels may intrude upon the tracheal lumen but can usually be bypassed by an endotracheal tube of firm consistency

Patents with cleft lip and palate present problems owing to difficulties which are partly anatomical The cleft can be packed to provide support for the laryngoscope and help prevent damage, but the mandible is often very underdeveloped

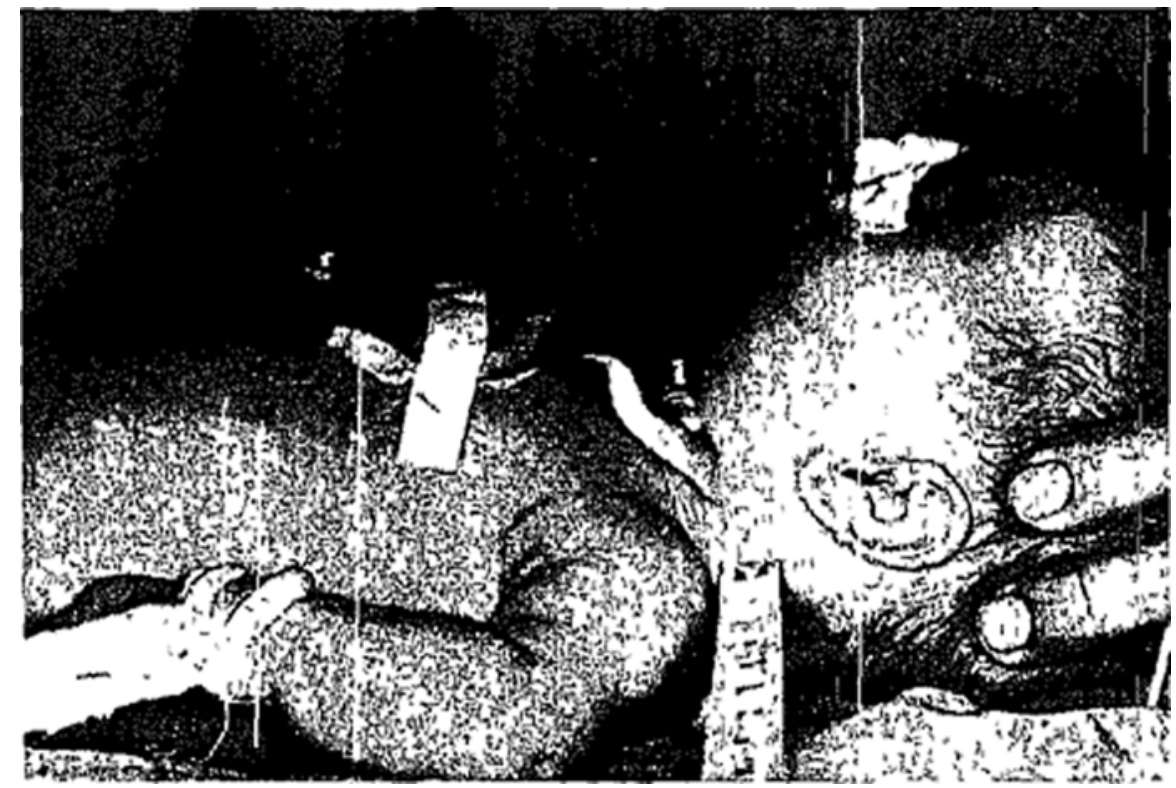

Ficune 4 A picture of an unfant with Pyerre-Robin syndiome of congenital deformities glossoptosis, micrognathus, and cleft palate The arway could only be mantaned by tric heostomy 
so that the tongue is more caudad and posterior and makes visualization of the larynx difficult Such micrognathus and tongue displacement are extreme in the Plerre-Robin syndrome (14) (F1g 4) In children with this syndrome intubation is well ngh impossible, but muld degrees of underdevelopment of the jaw and displacement of the tongue can occur wthout any other recognizable congental $\operatorname{defect}^{ \pm}($Fug 5 ) and are troublesome during intubation

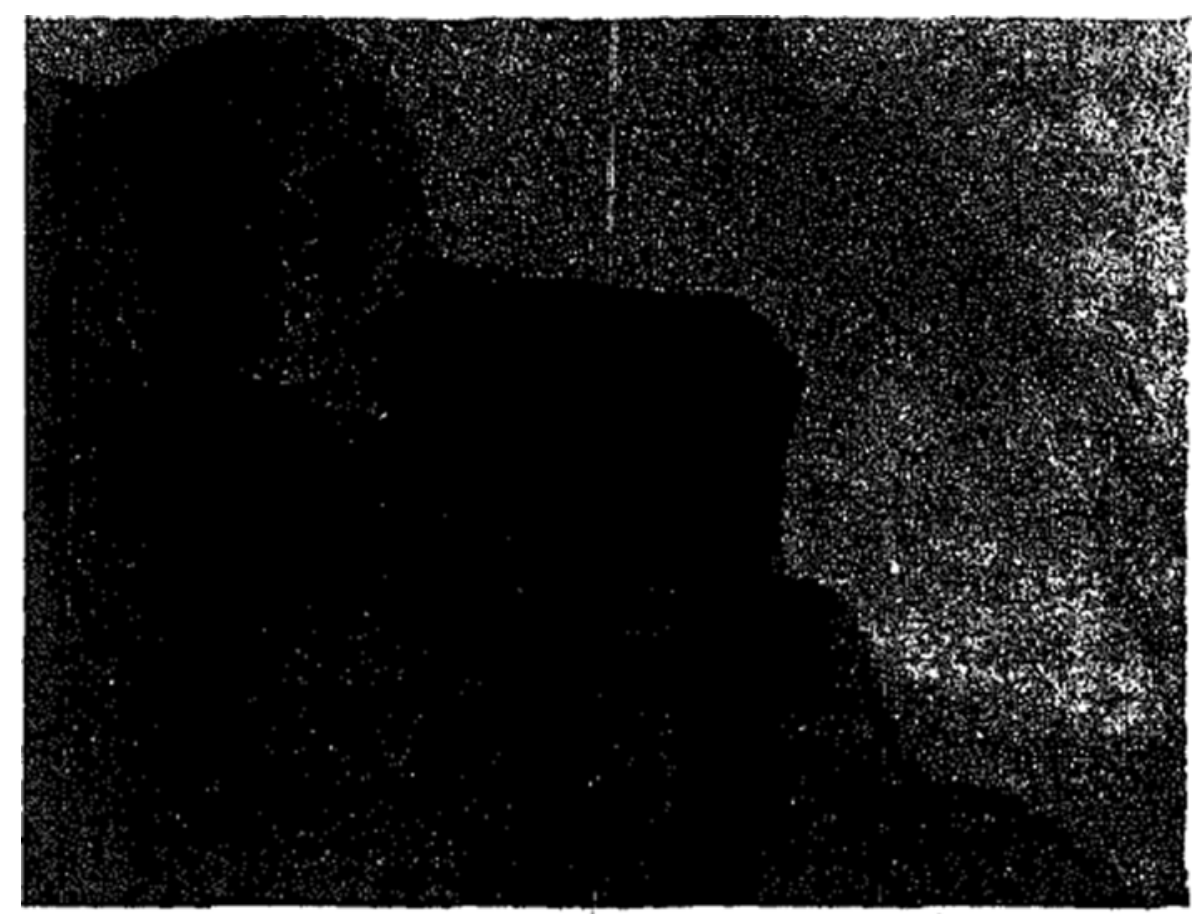

Figuir 5 A 5-vcar-old child with marked protrusion of the maxllat which made direct laryngoscopy diffienlt She had no other abnomality

The infective swellings which occu just below and above the glottis, which we call tracheobronchitus and epiglottitis respectuvely, are best treated with tracheotomy if severe Intubation followed by general anaesthesia is used for this operation In most instances, a pliable narrow-bore, woven gum-elastic catheter will bypass the obstruction, but a small bronchoscope may have to be utilized and should always be avalable (15), ( $F_{1 g} 6$ ) The vocal cords of the patient with tracheobronchitus are easily seen and the main difficulty is to clear the lower tracts of debris immediately after intubation In severe epiglottits visualization of the cords is often impossible, but tie lower passages may be freely entered if a small-boic, seml-stiff tube with an acute anten or curve at its extremity is duected below the central epiglotic raphe, which usually persists Severe suppuration of the pharynx, now seldom seen, may be retropharyngeal, peritonsilar, or duffuse (Ludwig's Angına) In all such conditions only mumimal topical or general analgesia without intubation is recommended, together with steep Trendelenburg posture if incision and dramage are requied, otherwise, preoperative tracheotomy with local analgesıa is mandatory A diphtheritic membrane is maunly a historical entıty, but like a post-intubation slough can occur and may call for 
endoscopic removal We do not favour the use of rigid stilettes within endotracheal tubes for chldren and infants because of the damage they may cause

Occasionally the surgical treatment itself may make intubation difficult, examples being cervical and head plasters (16) and Abbe-flap grafts In such operatons nasal intubation with inhalation anaesthesia or preanaesthetie removal of the cause of partial obstruction of the arway is advisable

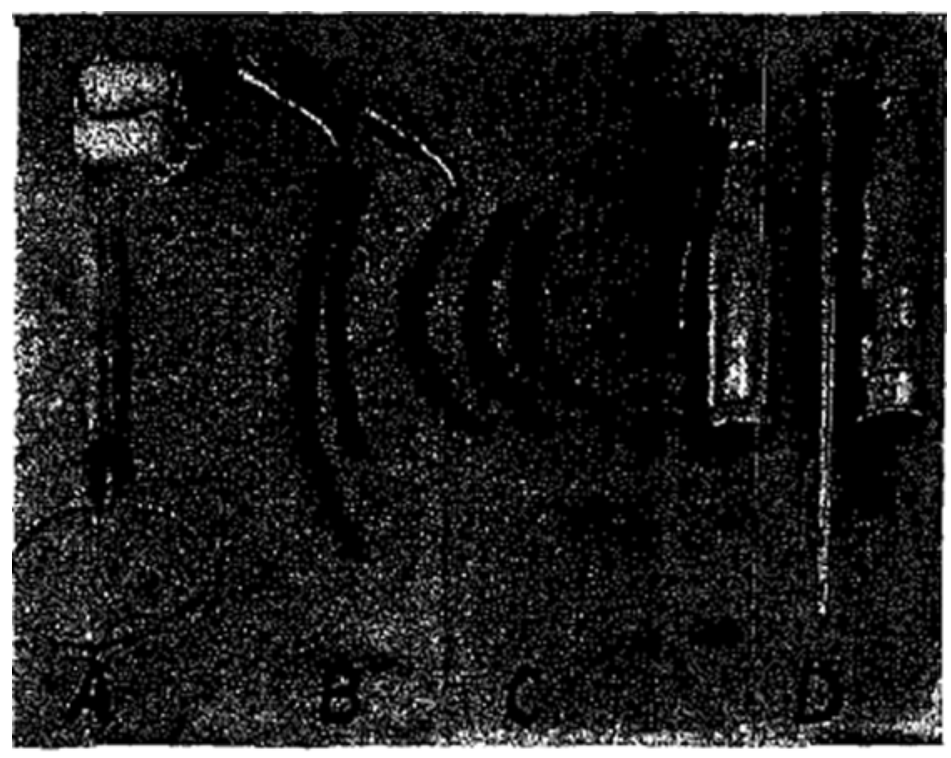

Figure 6 Some apparatus used for defficult tracheal satubation in infants $A$, suction catheters and bite blocks, B, gumelastic tubes, $\mathrm{C}$, Coles tubes with McGill connectors, D, infant Flagg laryngoscope and bronchoscope

\section{Anaesthetic Problems}

Induction of anaesthesia to a state in which intubation is possible presents some special problems in the infant or chuld In the newborn period inhalation of agents is a slow procedure and intravenous methods technically exacting Also, if anaesthesia is necessary in patents with severe respuratory tract obstruction, an whalation method is preferable and induction may be very prolonged

Laryngeal and cardiac rellexes are very active in children and not easily subdued, so that over-activity is more common than in adults and sometimes troublesome

\section{Conszderation of Anaesthetrc Problems}

With the agents at present avalable, it is a good rule to avoid attempts to untubate the trachea with only partial muscular relaxation Thus, patients must be either conscious or near the third plane of anaesthesia or fully paralysed with a relaxant This rule is most applicable in infants or chuldren if severe reflexes and local damage are to be avorded

In newly born infants the natural aurway is very difficult to maintain durng anaesthesia and, as they have little muscular power, it is preferable always to perform intubation in the conscious state In children with severe upper respira- 
tory obstuction it is impossible to mantain a natural arway while rendering them unconscious or flaccid and in extrems intubation must be attempted withoui giving any general anaesthetic or relaxant Forunately, the remaining muscular power is munimal in such exhausted patients and intubation while the child is conscious is relatively simple Intubation is most desirable to make the tracheotomy operation tranquil and safe

Hyperventlation of infants wh oxygen sometmes provides extra relaxation before intubaton (17) but this technique may have a dubrous physiological basis (18) There is evidence that denitrogenation of the lungs with oxygen before intubation in all pataents may make the procedure much safer (19) However, if an asphyxiated chuld struggles violently when oxygen adminustration is attempted, it is best stopped until the arrway is clear Prolonged preoperative oxygen or oxygen helium therapy seems clnncally most advantageous when possible

The relaxants, while facilitatung intubation without local damage, often make it difficult to keep the natural arway patent during the penod of partal paralysis until the drug is fully effective This feature is most obvious in very small children and may be related to the crowded anatomy of the pharynx Thus for intubation we prefer the rapidly actung relaxants by the intravenous route to those given intramuscularly or those in whrch the onset is inherently slow It is possible that newborn unfants are susceptible to the non depolarizing relaxants and resistant to the depolarizing agents $(20)$, and that the former must be used with special caution in the very yøung Succinylcholine chloride may have some drect effect upon the cardiovascular system of young patients (21) If relaxants are used in the young patient, a means of rapid change to the endotracheal attachment is vitally necessary on the andesthetic machme be it with a good assistant or a 'switch over mechanism so that artificial respiration may be begun with a minimum of delay

Conditions which complicate induction of anaesthesia in any age group, such as full stomach and haemorrhage in the upper aurway have to be considered as associated with the difficulties of intubation as intubation is requred for the best handlung of the maintenance of anaesthesia in these patients The only safe method (that is, intubaton while conscious) is restricted un strong children even with the most efficient topical anaesthesia, and none of the present recommended methods is completely satisfactory (22) However, in a child or infant it is extremely rare that an operatoon is so vitally urgent that some delay cannot be entertained if the stomach is likely to be full and, if the operation is urgent, a large tube may easily be passed into the stomach and any discomfort so caused should be overlooked There now seems to be no valid reason to insist that a normal diet be given at regular times to an infant either just before or just after a modern anaesthetic we substitute 5 per cent glucose water solution for two or three feedings and do not permit anything orally for at least four hours before operation

Experienced anaesthetsts are inclmed nowadays to use rapid technıques for intubaton and in the adult this often enables one to handle any eventuality more edsily In infants or children, when axkward conditons present, the simpler inhalation induction is usually safer although laborious 


\section{Discussion}

Endotracheal intubation is becoming very cornmonplace, but there is still a tendency to avoid its use in children and infants. This prejudice arose primarily from a fear of post-intubation oedema, which was thought to be due to the necessary instrumentation. With the use of new plastic endotracheal tubes of appropriate size, which are properly sterilized, and a better understanding of electrolyte balance, experience has shown that the procedure rarely leads to any sequelae.

If one considers the anatomy of the immature airway and the ease with which it becomes impaired, together with the dire consequences to the infant or child of slightly obstructed ventilation, it is probable that endotracheal intubation will eventually be more commonly used with great justification.

Although there are problems, it is obvious that there are no more difficulties to endotracheal intubation in one age group than in another. Only the difficulties which arise while the tube is actually being inserted have been discusssed but, while being equally mindful of the serious things which may occur during or after intubation, it will be found that they are of no greater frequency in one age group than in another if our knowledge is fully applied.

Relaxants are becoming more popular in paediatric anaesthesia, but their dangerous properties are not fully understood yet and they should be used only by those very experienced in this work and then most cautiously, particularly before intubation. At present it would seem best for most of us tọ be careful rather than crafty in our use of new agents to accomplish endotracheal intubation in young patients, as the smallest error may lead to disaster.

\section{SUMMARY}

Some significant anatomical and anaesthetic problems associated with direct laryngoscopy and endotracheal intubation in infants and children are considered.

Our practice of using endotracheal intubation for the majority of patients whom the Department of Anaesthesia is asked to treat in the Montreal Children's Hospital leads us to the conclusion that careful methods will ensure that it is a simple practice which adds to the safety of our management. The difficulties encountered are different but no more frequent than in other age groups, and our attempts to deal with some of these difficulties have been described.

\section{RÉSUMÉ}

Les problèmes que pose l'intubation endotrachéale chez les enfants proviennent soit des particularités de leur anatomie, soit des exigences de l'anesthésie.

A cause de la position antérieure et plus céphalade du larynx, il est préférable d'utiliser une lame plate 'tout en observant la technique particulière à l'emploi de la lame de MacIntosh. Une pression en direction postérieure appliquée dans la fossette glosso-épiglottique en avant du larynx donne une bonne visualisation de la glotte; un tube de plastique, mou, presque droit peut alors être introduit 
sans difficultés. Chez les jeunes enfants, il faut faire attention aux bourgeons dentaires pour éviter des malformations subséquentes. L'intubation nasale a des indications spécifiques et bien limitées, et demeure une opération délicate. Même si, chez les nouveaux-nés, les manipulations sont facilitées par une technique minutieuse, et l'emploi de laryngoscopes dont les lames sont à angle obtus, il est important que le diamètre de l'instrument soit petit, la lame courte et son bout mousse.

Chez les nouveaux-nés, linduction présente des problèmes particuliers du fait que les agents d'inhalation sont lents à agir et que les agents intraveineux sont difficiles à administrer. Il faut aussi se rappeler que le nouveau-né a de la difficulté à maintenir des échanges respiratoires adéquats durant l'anesthésie et toujours pratiquer l'intubation à l'état de veille facilitée chez celui-ci par son peu de résistance musculaire. Cette technique d'intubation à l'état de veille est indiquée aussi et chez les erfants in extremis et chez ceux qui sont en détresse respiratoire, chez qui il devient impossible de maintenir des échanges adéquats lors qu'on les rend inconscients et flaccides. L'hyperventilation à l'oxygène procure souvent un relâchement musculaire supplémentaire avant l'intubation et il semble que la dénitrogénation des poumons à l'oxygène ajoute un facteur de sécurité à tous les âges. On préfère l'administration par voie intraveineuse de relaxants musculaires à action rapide pour faciliter lintubation; toutefois, les nouveaux-nés semblent réfractaires à l'action des relaxants dépolarisants et particulıèrement sensibles à celle des agents non-dépolarisants. Ces derniers doivent donc être utilisés avec précaution chez les tout jeunes. La succinylcholine semblerait avoir un effet direct sur le système cardiovasculaire des enfants.

L'emploi d'une technique rigoureuse, de tubes endotrachéaux en plastique, de calıbre adéquat et stérilisés avec soin, associé à une meilleure compréhension de l'importance d'un bon équilibre électrolytique font de l'intubation endotrachéale une technique plus sûre qui se complique rarement de séquelles.

\section{REFERENCES}

1 Pender, J W Endotracheal Anaesthesia in children Advantages and Disadvantages. Anesthesiology 15495 (1954).

2 Eckenhoff, J. E. Some Anatomical Considerations of the Infant Larynx influencing Endotracheal Anesthesia. Anesthesiology 12401 (1951)

3. Sillman, J H. Serial Study of Occlusion (Birth to Ten Years of Age). Am. J. Orthodont. 34969 (1948).

4. Bannister, F B, \& MacBeth, $\mathrm{R}$ G Drrect Laryngoscopy and Tracheal Intubation. Lancet 11651 (1944).

5. MacIntosh, R. R. A New Laryngoscope. Lancet 1205 (1943).

6. Morch, E T A New Laryngoscope Anesth. \& Analg 30358 (1951)

p. Hollinger, P H, \& Johnston, K C Factors Responsible for Laryngeal Obstruction - in Infants J.A.M.A. 1431229 (1950).

8. Dwyer, C S, KronenberG, S., \& Saklad, M The Endotracheal Tube A Consideration of its Traumatic Effects with a Suggestion for the Modification Thereof. Anesthesiology $10714(1949)$.

9 Ramaker, $\mathrm{R}$ E The Effect of Abnormal Pressure Factors during Birth upon the Maxilla, Nasal Bones and Dental Arches. Northwest Dent. 18.150 (1939).

10. Sмrтth, R. M. Infant Laryngoscope. Anesthesiology 17364 (1956). 
11. MacBeth, R. G, \& Bannister, F. B A New Laryngoscope. Lancet 11.654 (1944).

12. Barnard, J. An Unusual Accident during Intubation Anaesthesia 3:126 (1948)

13. Devens, A. M, \& OtIs, R. D. Tracheal Atresia associated with Tracheo-oesophageal Fistula. J. Thoracic Surg. 34.405 (1957).

14. Mrtchell-Nelson. Textbook of Pediatrics, p. 766 5th ed Philadelphia Saunders (1950).

15. Bryce-Smith, R. An Anaesthetic Technique for Tracheostomy Anaesthesia 12:152 (1957).

16 Thomas, D. V. Anesthesia in Operations for Scoliosis Anesth. \& Analg. 3634 (1957).

17. Rees, G. J. Anaesthesiá in the Newborn. Bnt. Med. J. 2.1419 (1950).

18. Cuurton-Brock, J. The Cerebral Effects of Overventilation, Bnt J Anaesth. 29.111 (1957).

19. Jacoby, J.; Zeigler, G, Hamelberg, W., Mogg, A, Klessen, K, \& Florg, F Cardiac Arrhythma. Effect of Vagal Stımulation and Hypoxia Anesthesiology 16.104 (1955).

20. Stead, A. L. The Response of the Newborn Infant to Muscle Relaxants. Brit J Anaesth. 27:124 (1955).

21. Leigh, M. D., McCoy, D M ; Belton, M. K, \& Lewis, G. B Bradycardia following Intravenous Adminstration of Succinylcholine Chloride to Infants and Children Anesthesiology 18:698 (1957).

22. Morton, H. J. V., \& WyLIE, W. D. Anaesthetve Dealhs due to Regurgitation and Vomiting. Anaesthesia 6:190 (1951). 